\title{
SUPERVISI AKADEMIK KEPALA SEKOLAH DALAM MENINGKATKAN PROFESIONALISME GURU PADA SMP NEGERI 1 NDONA KABUPATEN ENDE NUSA TENGGARA TIMUR
}

\author{
Agnes Remi Rando, S.Pd.,M.Pd \& Aschari Senjahari Rawe, S.E.,M.Pd \\ Email : ascharisenjaharirawe@gmail.com \\ Universitas Flores
}

\begin{abstract}
Abstraksi
Penelitian ini bertujuan untuk mengungkapkan program supervisi akademik dalam meningkatkan profesionalisme guru yang dilakukan oleh kepala sekolah SMP Negeri 1 Ndona.Pendekatan yang digunakan adalahkualitatif dengan metode deskriptifdan teknik pengumpulan data yang digunakan adalah dengan wawancara, observasi, dokumentasi.Hasil penelitian menunjukan bahwa supervisiakademik yang dilakukan oleh kepala sekolah berdampak sangat baik dalam rangka meningkatkan profesionalisme guru.Dari data yang ada menunjukan bahwa peran kepala sekolah dalam meningkatkan profesionalisme guru sangat baik dengan melakukan kegiatan-kegiatan penunjang dengan cara mengirim guru-guru untuk mengikuti berbagai pelatihanpelatihan, mengadakan pelatihan informasi dan teknologi, mengikutsertakan guru-guru dalam kegiatan musyawara guru mata pelajaran.

Kata Kunci : Supervisi Akademik, professional guru
\end{abstract}

\section{Abstraction}

This study aims to reveal the academic supervision program in increasing teacher professionalism conducted by the Ndona 1 Public Middle School. The approach used is qualitative with descriptive methods and data collection techniques used are interviews, observation, documentation. The results of the study show that the academic supervision carried out by School failure has a very good impact in order to increase the professionalism of teachers. From the available data, it shows that the role of principals in increasing teacher professionalism is very good by carrying out supporting activities by sending teachers to participate in various trainings, holding information and technology training, involving teachers in the subject teacher discussion activities.

Keywords: Academic supervision, professional teachers 


\section{PENDAHULUAN}

Sistem pendidikan Nasional adalah suatu keseluruhan yang terpadu dari semua system dan kegiatan pendidikan yang berkaitan satu dengan yang lainnya untuk tercpaainya pendidikan Nasioanal. Dengan berlakunya Undang-undang Republik Indonesia No. 20 tahun 2003 tentang system pendidikan Nasional berfungsi mencerdaskan kehidupan bangsa melalui pengembangan kemampuan serta membentuk watak dan peradaban bangsa yang bermartabat ditengah masyarakat dunia serta peraturan pemerintah sebagai pedoman pelaksana maka kurikulum sekolah lanjutan tingakat pertama disesuiakan dengan peraturan perundang-undangan.

Penyesuaian ini mengakibatkan perluhnya upaya yang harus dilakukan agar tercapai tujuan pendidikan. Supervise dianggap perluh dan sangat penting atas pertimbangan yaitu pertama perkembangan informasimelalui berbagai media karena itu perluhnya perubahan kurikulum sekolahsekolah secara terus menerus agar sekolah tidak ketinggalan zaman. Yang kedua bahwa para guru adalah manusia yang memiliki kelebihan-dan kekurangan.Kegiatan pokok supervis adalah melakukan pembinaan terhadap guru pada khususnya agar kualitas pembelajaran meningkat dan juga dapat meningkatkan kulitas lulusan itu sendiri.

Supervise akademik menjadi salah satu cara untuk mencapai apa yang diharapkan dan dapat menjawapi persoalan yang ada. Supervise akademi lebih menitikberatkan pengamatan pada masalah akademik yaitu langsung berada dalam lingkup kegiatan pembelajaran yang dilakukan oleh guru untuk membantu siswa ketika dalam proses belajar. Objek utama supervise akademik adalah aspekaspek akademik yang langsung berada dalam lingkungan pembelajaran.

Menurut dewei (2001;23), tugas sekolah adalah memberi pengalaman belajar yang tepat bagi peserta didik dan guru sebagai pemegang peranan yang sangat penting dalam proses pembelajaran. Ditegaskan bahwa tugas guru adalah membantu peserta didik menjalin pengalaman belajar yang satu dengan yang lain serta guru harus mengetahui kesulitan-kesulitan yang dihadapi oleh peserta didik. Agar tugas guru dapat berjalan dengan baik maka diperluhkan peran kepala sekolah.

Peran kepala sekolah adalah menggerakan, mempengaruhi, memotivasi, mengajak, mengarahkan, menasehati, membimbing agar guru sebagai media mau bekerja dalam rangka mencapai tujuan.Tugas pokok kepala sekolah adalah a) menyusun program sekolah secara keseluruhan, b) mendelegasikan tanggung jawab pelaksanaan disekolah, c) menyediakan dan melengkapi kebutuhan fasilitas sekolah, d) mengadakan hubungan dengan lembaga-lembaga diluar sekolah.Selain itu tujuan lainnya adalah a) membantu guru-guru memahami, b) memilih dan merumuskan tujuan pendidikan yang akan dicapai, c) menggerakan guru-guru, karyawan, siswa dan anggota masyarakat untk mensukseskan program pendidikan disekolah, c) menciptakan sekolah sebagai suatu lingkungan kerja yang harmonis, sehat, dinamis dan nyaman sehingga segenap anggota dapat bekerja dengan penuh produktivitas dan memperoleh kepuasan kerja yang tinggi (Kusmintodjo, 1990:32).

Peningkatan kemampuan guru akan berpengaruh terhadap peningkatan lulusanpeserta didik yang menjadi tanggung jawabnya. Pengajaran merupakan aspek utama dalam sekolah yang dapat diperbaiki dan ditingkatkan dengan memberikan bimbingan dan layanan professional pada mereka yang bertanggung jawab dalam menjalankan tugas akademik.Bantuan untuk mengembangkan kemampuan guru dalam bekerja merupakan sebuah kondisi yang sangat diperlukan jika guru-guru ingin berkembang kearah yang lebih baik sesuai dengan perubahan lembaga yang diinginkan.

\section{Tinjauan Pustaka}

\section{Kepala Sekolah}

Peran kepala sekolah adalah untuk menggerakan, mempengaruhi, mengajak, mengarahkan, menasehati, membimbing dengan maksud agar manusia sebagai media manajemen mau bekerja dalam rangka mencapai tujuan administrasi secara efisien.Tugas pokok kepala sekolah adalah menyusun program sekolah secara keseluruhan, mendelegasikan tanggung jawab pelaksanaan disekolah, mengawasi pelaksanaan program disekolah, menyediakan dan melengkapi kebutuhan fasilitas, mengadakan hubungan dengan lembagalembaga diluar sekolah.

Sebagi pemimpin disekolah kepala sekolah memiliki berbagai fungsi dan fungsi itu perluh dijabarkan dalam bentuk tindakan kepada guru dan siswa untuk melaksanakan kegiatan pendidikan dan pembelajaran (Mulyasa E, 2003:67-73). Fungsifungsi itu antara lain:

1. Kepala sekolah sebagai edukator (Pendidik). Kepala sekolah harus memiliki berbagai strategi yang tepat untuk meningkatkan profesionalisme tenaga kependidikan disekolahnya, menciptakan iklim sekolah yang kondusif, memberikan nasehat kepada warga sekolah, memberikan motivasi kepada seluruh tenaga kependidikan serta 
melaksanakan model pembelajaran yang menarik.

2. Kepala sekolah sebagai manajer

Kepala sekolah harus memiliki strategi yang tepat untuk memberdayakan tenaga kependidikan melalui kerja sama dan memberi kesempatan kepada para tenaga kependidikan untuk meningkatkan profesinya dan mendorong keterlibatan seluruh tenaga kependidikan dalam berbagai kegiatan yang menunjang program sekolah.

3. Kepala sekolah sebagai administrator Sebagai administrator kepala sekolah harus memiliki hubungan yang erat dengan berbagai aktivitas pengelolahan administrasi yang bersifat pencatatan, penyusunan, dan pendokumentasian seluruh program sekolah.

4. Kepala sekolah sebagai supervise

Sebagai supervisor harus diwujudkan dalam kemampuan menyusun dan melaksanakan program supervisi pendidikan serta memanfaatkan hasilnya.

5. Kepala sekolah sebagai leader

Kepala sekolah harus mampuh memberikan petunjuk dan penguasaan, meningkatkan kemajuan tenaga kependidikan, membuka komunikasi dua arah dan mendelegasikan tugas.

6. Kepala sekolah sebagai motivator

Sebagai motivator kepala sekolah harus memiliki strategi yang tepat untuk memberikan motivasi kepada para tenaga kependidikan dalam melakukan berbagai tugas dan fungsinya.

7. Kepala sekolah sebagai innovator

Sebagai innovator kepala sekolah harus mampuh mencari, menemukan dan melaksanakan berbagai pembaharuan disekolah.Gagasan baru tersebut misalnya moving class.Moving class adalah mengubah strategi pembelajaran dan pola kelas tetap menjadi kelas bidang studi sehingga setiap bidang studi memiliki kelas tersendiri yang dilengapi dengan alat peraga dan alat-alat lainnya (Mulyasa, 2004:98-120).

\section{Supervisi akademik}

Supervisi akademik adalah serangkaian kegiatan membantu guru mengembangkan kemampuannya mengelola proses pembelajaran untuk mencapai tujuan pembelajaran (Daresh, 1989, Glickman, et al. 2007). Supervisi akademik tidak terlepas dari penilaian kinerja guru dalam mengelola pembelajaran. Apa yang telah dilakukan oleh guru dalam mencapai tujuan akademik?, apa kelebihan dan kekurangan guru dan bagaimana cara mengembangkannya? Berdasarkan jawaban terhadap pertanyaan-pertanyaan ini akan diperoleh informasi mengenai kemampuan guru dalam mengelola pembelajaran

Supervisi akademik adalah supervisi yang menitik beratkan pengamatan pada masalah akademik yaitu yang langsung berada dalam lingkungan kegiatan pembelajaran yang dilakukan oleh guru untuk membantu siswa ketika dalam proses belajar. Dalam konteks pembelajaran peserta didik diposisikan sebagai subjek belajar yang memegang peran utama sehingga dalam proses belajar mengajar siswa dituntut beraktifitas secara penuh bahkan secara individual mempelajari bahan pembelajara.

Kuriklum berbasis kompetensi pada pengalaman belajar sesuai dengan prinsip belajar sepanjang hayat yang mengacu pada empat pilar pendidikan. Pembelajaran yang dilakukan oleh guru harus mengacu pada pendekatan pembelajaran yang akan digunakan termasuk pembelajaran, lingkungan pembelajaran dan pengelolaan kelas (Trianto, 2007:37).Setiap model pembelajaran mengarahkan kita dalam merancang pembelajaran untuk membantu peserta didik mencapai tujuan pembelajaran.

\section{Program supervise akademik}

Guru merupakan sumber daya yang harus dibina dan dikembankan terus menerus. Pembentukan professional guru harus dilaksanakan melalui program pendidikan pra-jabatan (pre-service education) maupun program dalam jabatan (inservice education).

Supervise akademik diberikan kepada guru-guru disekolah baik guru kelas maupun guru mata pelajaran. Guru-guru perluh mendapat pembinaan dari para pembina pendidikan yang disebut supervisor. Dalam pengalaman dan pengamatan dilapangan kebanyakan masalah yang timbul dalam proses pembelajaran dikelas bukan pada kurangnya pengetahuan tentang teknik mengajar tapi karena putus mata ranrai yaitu hubungan kemanusian antara guru dan peserta didik. Secara psikologi menciptakan situasi belajar mengajar yang membangkitkan dorongan emosional berupa lambang-lambang dalam bentuk kata persekutuan seperti senyum, memberi hormat, tentang akan memberi semangat baru dalam proses pebelajaran dikelas.

Untuk meningkatkan kualitas sumber daya diperlukan penilaian terus menerus.Dalam belajar mengajar peranan guru-peserta didik sangat penting. Supervise akademi akanmemperbaiki proses pembelajaran(Dadang, 2010). Sala satu usaha perbaikan proses belajar mengajar adalah melakukan supervisi akademik yang dilakukan oleh supervisor. Supervisor dapat membantu guru-guru 
untuk mengembangkan berbagai model rancangan pembelajaran. Adapun program yang harus diperhatikan dalam supervise akademik yakni:

\section{Identifikasi aspek-aspek}

Supervisor perluh menelaa secara seksama program intruksional untuk menetapkan aspekaspek mana yang paling dibutuhkan untuk perbaikan. Apakah relevansi ini dapat ditentukan dengan suatu penelaahan yang seksama terhadap program-program instruksional didasarkan pada informasi yang dapat dipercaya dari:

a. Hasil tes yang telah distandarlisasi

b. Hasil-hasil tes susunan guru sendiri

c. Partisipasi murid dalam pembelajaran

d. Menyelesaikan tugas-tugas

2. Perumusan tujuan program

Supervisor perluh merumuskan secara jelas tujuan untuk mendukung program supervisinya. Ada persamaan antara tujuan instruksional dengan tujuan supervise. Jika tujuan program supervise adalah untuk memberikan pengarahan terhadap aktivitas pembelajaran maka tuuan itu hendaknya dirumuskan secara jelas sehingga terhindardari salah penafsiran. Tujuan program supervise yang dirumuskan hendaknya disimpulkan dari kebutuhan sekolah demi perbaikan dan peningkatan mutu pendidikan dan pengajaran.

3. Penentuan aktivitas-aktivitas

Perluh penentuan aktivitas dan kegiatan yang sepadan untuk mencapai tujuan program supervise yang ditetapkan. Aktivitas dan kegiatan itu harus saling berinteraksi untuk mencapai keefektivan yang maksimal.

4. Perumusan kriteria evaluative

Untuk menentukan sejauhmana perbaikanperbaikan atau peningkatan yang telah dilaksanankan maka supervisor perluh menetapkan kriteria evaluasinya. Dalam hubungan ini evaluasi harus dihubungkan dengan tujuan yang telah ditetapkan .evaluasi yang dimaksud hendaknya cukup komperhensif sehingga mencakup aspek dari situasi pembelajaran.

Umumnya alat atau teknik dapat dilakukan dalam dua macam yaitu teknik yang bersifat individual adalah teknik yang dilaksanakan untuk seorang guru secara individual dan teknik yang bersifat kelompok yaitu teknik yang dilakukan untuk melayani lebih dari satu orang.

1. Teknik yang bersifat individual

a. Perkunjungan kelas

Tujuan untuk memperoleh data mengenai keadaan sebenarnya selama guru mengajar.Dengan data itu supervisor dapat berbincang-bincang dengan guru tentang kesulitan yang dihadapi guru-guru.
Kunjungan ini dapat memberi kesempatankepada guru-guru untuk mengungkap pengalamannya sekaligus sebagai usaha untuk memberikan rasa mampuh pada guru-guru.

Tiga cara berkunjung kelas:

* Perkunjungan tanpa diberitahu; supervisor tiba-tiba datang kekelas tanpa memberitahukan terlebih dahul

* Perkunjungan dengan cara memberitahu terlebih dahulu; biasanya supervisor telah memberkan jadwal perkunjungan sehingga guru-guru tahu pada hari dan jam ia dikunjungi.

* Perkunjungan atas undangan gur; perkunjngan ini akan lebih baik, oleh karena itu guru punya usaha dan motivasi untuk mempesiapkan diri dan membuka diri agar di dapat memperoleh pengalaman baru dari hal kunuungan supervisor.

b. Observasi kelas

Melalui perkunjungan kelas supervisor dapat mengobservasi situasi belajar mengajar yang sebenarnya

Ada dua macam observasi kelas:

* Observasi langsung; dengan menggunakan alat observasi supervisor mencatat absen yang dilihat pada saat guru sedang mengajar

* Observasi tidak langsung; orang yang melakukan observasi dibatasi oleh ruang dimana siswa tidak mengetahuinya. (biasanya dilakukan dalam laboratorium untuk mengajar mikro). Observasi ini dilakukan untuk memperoleh data yang seobjektif mungkin sehngga bahan yang diperoleh dapat digunakan untuk menganalisis kesulitankesulitan yang dihadapai guru dalam usaha memperbaiki proses pembelajaran.

Hal-hal yang diobservasi antara lain; usaha dan kegatan antara guru dan siswa dalam hubungan dengan penggunaan bahan dan alat pelajaran, usaha dan kegiatan guru dan siswa dalam memperoleh pengalaman belajar.

c. Wawancara

Banyak keuntungan dilakukannya wawancara, karena apa yang diperoleh supervisor adalah pendapat murni dari pribadi yang diwawancara. Hal ini dilakukan untuk mengetahui kebenaran data yang sudah dikumpulkan sebelumnya.

2. Teknik kelompok

a. Mengadakan pertemuan atau rapat 
Fungsi komunikasi dalam sekolah dapat terlaksana dengan baik apabila masingmasing warga sekolah mempunya hak yang sama untuk mengemukakan pendapat.

b. Mengadakan diskusikelompok; diskusi kelompok bertujuan untuk mengumpulkan data. Sekolah juga dapat mengadakan pertemuan khusus yang dihadiri oleh guru mata pelajaran.

c. Mengadakan penataran; penataran merupakan sala satu wadah untuk meningkatkan kemampuan guru dan staf sekolah. Penatara dikategorikan in-service training.

d. Seminar

\section{Profesionalisme guru}

Profesionalisme menunjuk pada komitmen para anggota pada suatu profesi untuk meningkatkan kemampuan profesionalnya dan terus menerus mengembangkan strategi yang digunakan dalam melakukan pekerjaan yang sesuai dengan profesinya.Professional menunjuk pada dua hal, pertama penampilan seseorang sebagai professional atau penamilan suatu pekerjaan sebagai profesi.Professional juga mengau pada sikap dan komitmen untuk bekerja berdasrkan standard yang tinggi dank ode etik profesinya.

Guru yang professional memiliki kompetensi dalam melaksanakan program pembelajan.Pengertian dasar dari kompetensi adalah kemampuan dan kecakapan seseorang yang dinyatakan kompoten dibidang tertentu adalah seseorang yang menguasai kecakapan kerja atau keahlian selaras dengan tuntutan bidang kerja yang bersangkutan.

Guru yang memiliki kompetensi professional perluh menguasai antara lain;

a) Disiplin ilmu sebagai sumber belajar

b) Memiliki bahan ajar

c) Memiliki pengetahuan tentang karakteristik siswa

d) Memiliki pengetahuan tentang filsafat dan tujuan pendidikan

e) Memiliki pengetahuan serta penguasaan metode dan model pengajaran

f) Penguasaan terhadap prinsip-prinsip teknologi pembelajaran

g) Memiliki pengetahuan terhadap penilaian dan mampuh merencanakan, memimpih guna kelancaran proses pendidikan.

\section{Ciri-ciri profesi guru}

Adapun ciri-ciri dan syarat profesi yang dikemukakan oleh (Arikunto, 1990) adalah sebagai berikut:

1) lebih mementingkan pelayanan kemanusiaann yang ideal dibandingkan dengan kepentingan pribadi

2) seorang peketrja professional secara aktif memrlukan waktu yang panjang untuk mempelajari konsep-konsep serta prinsip pengetahuan khusus yang mendukung keahliannya

3) memiliki kualifikasi tertentuntuk memasuki proses tersebut serta mampuh mengikuti perkembangan dalam pertumbuhan jabatan.

4) memiliki kode etik yang mengatur keanggotaan, tingkah laku, sikap dan cara kerja.

5) membutuhkan suatu kegiatan ineklektual yang tinggi

6) adanya organisasi yang dapat meningkatkan standard pelayanan, disiplin diri dan profesi suatu karier hidup dan menjadi seorang anggota yang permanen.

Ciri dan syarat diatas dapat digunakan sebagai kriteria atau tolak ukur keprofesiaan guru. Kriteria ini akan berfungsi ganda yaitu untuk mengukur sejauh mana guru telah memenuhi kriteria professional dan kriteria ini dijadikan sebagai tujuan yang mengarahkan segalah upayah menuju profesionalisme guru.

Sebagai suatau profesi, seorang guru harus berusaha agar pengetahuan yang dimiliki merupakan pengetahuan yang tangguh dan tahan uji. Karena bila tidak demikian ia akan ketinggalan jaman dan lebih rugi lagi adalah peserta didik. Seorang guru harus mementingkan kepentingan orang lain (kepentingan peserta didik) diatas kepentingan diri sendiri, dengan demikian guru akan mendapatkan penghargaan dan penghormatan dari orang lain.

\section{Tindak lanjut dalam peningkatan profesionalisme guru}

Supervise akademik yang diberikan kepada guru dalam tugas mengajar dan mendidik dalam usaha memotifasi guru dalam meningkatkan profesionalisme adalah:

1. Membantuh guru dalam menerjemehkan kurikulum kedalam sejumlah pengalaman belajar yang dirancang dibawah tanggung jawab 
sekolah dalam rangkah mencapai tujuan yang telah ditetapkan.

2. Membantu guru dalam meningkatkan program belajar mengajar. Untuk meningkatkan kemampuan guru dalam proses belajar mengajar, belajar tidak sekedar mengkomunikasikan pengetahuan agar diketahui subjek didik. Tetapi mengajar harus diartikan menolong siswa agar mampuh memahami konsep-konsep dan dapat menerapkan konsep yang dipahami. Guru diberi motivasi agar selalu berusaha untuk merancang apa yang akan disajikan mempersiapkan diri agar tampil dalam mengajar dan menilai dengan tepat serta bertanggung jawab atas tugas mengajarnya. Bantuanyang diberikan kepada guru dalam hal: merancang program belajar mengajar, melaksanakan proses belajar mengajar, menilai proses dan hasil belajar, mengembangkan manajemen kelas

Bantuan yang diberikan kepada guru dalam hal:

* Merancang program belajar mengajar Guru harus bisa merancang program pembelajaran dan harus mengasai dan berlatih dalam menyusun scenario pembelajaran

* Melaksanakan proses belajar mengajar Guru harus menguasai sejumlah keterampilan dalam menemukan cara berpikir peserta didik dalam proses pembelajaran, keterampilan dalam menjelaskan, bertanya, memberikan penguatan.

* Menilai proses dan hasil belajar

Mengenai proses penilaian yang perluh dibina adalah pemahaman konsep tentang proses dan hasil penilaian. Guru perluh memahami dengan jelas antara pengukuran dan penilaian.

* Mengembangkan manajemen kelas Guru harus bisa menciptakan suasana kelas yang menyenangkan. Suasana belajar yang menyenangkan mendorong gairag belajar tinggi.

\section{METODE PENELITIAN}

Peneltian ini menggunakan pendekatan kuailitatif dengan metode deskriptif, yang memberikan kesempatan bagi peneliti untuk mendeskripsikan temuan-temuan lapangan.Penelitian ini dilakukan di Sekolah Menengan Pertama Negeri 1 Ndona Kabupaten Ende Nusa Tenggara Timur dan subjek dalam penelitian ini adalah kepala sekolah dan guru-guru.Teknik pengumpulan data yang digunakan adalah wawancara, Observasi, metode dokumentasi.

\section{HASIL DAN PEMBAHASAN}

\section{Program Supervise Akademik Kepala Sekolah}

Guru merupakan sumber daya manusia yang harus dibina dan dikembangkan terus menerus. Pembentukan profesionalisme guru harus dilksanakan mellui program pendidikan maupun program dalam jabatan. Guru sebagai suatu komponene sumber daya pendidikn memerlukan bantuan supervise akademik, supervise akademik diberikan kepada guru-guru disekolah baik dikelas maupun guru mata pelajaran (Arikunto;2004:43).

Dari hasil wawancara dengan kepala sekolah mengatakan bahwa program supervise akademik yang dilakuakn untuk membantu serta menilai guru secara langsung pada saat melakukan kegiatan pembelajaran. Yang disupervis adalah semua guru baik formal maupun informal.Bagi guru, yang disupervisi adalah administrasi dan perangkat pembelajaran yaani program tahunan, program semester, ketercapaian tujuan dan penilaian.Selain itu juga pemantauan secara lengkap saat proses pembelajaran berlangsung yang dilakukan guru dikelas.

\section{Profesionalisme Guru}

Usaha untuk meningkatkan dan mengembangkan potensi sumber daya guru dapat dilaksanakan berbagai alat dan teknik supervisi.Umumnya alat atau teknik dapat dilakuakn dalam dua macam yaitu bersifat individu yang dilaksanakan seorang guru secara individu dan Teknik yang bersifat kelompok yakni dilakukanlebih dari satu orang.

Dari hasil wawancara mengatakan bahwa teknik yang dilakukan bersifat individu yakni melalui pemeriksaan secara keseluruhan administrasi dan perkunjungan kelas, observasi dan wawancara terhadap guru.Perkunjungan kelas yang dilakukan biasanya diberitahu terlebih dahulu dan tanpa diberitah terlebih dahulu.Tapi yang sering dilakukan oleh kepala sekolah adalah perkunjungan tanpa diberitahu terlebih dahulu (dadakan) alasannya biasanay kalau diberitahu terlebih dahulu ada semacam rekayasa yang dilakuakn guru.Ia juga melakukan observasi kelas yang dilakukan secara langsung dan tidak langsung. Observsi langsung yakni kepala sekolah melihat proses pembelajaran yang dilakukn oleh guru apakah sesuai denganperangkat pembelajaran yang telaha dibuat atau tidak apa atau tidak sementara observasi tidak langsung dimana kepala sekolah melhat dari luar apakah proses pembelajaran dikelas berjalan baik atau tidak. Selain itu kepala sekolah mengadakan wawancaradengan guru yang sudah disupervisi sekaligus evaluasi atau perbaikan atas kekurangankekurangan yang dialami oleh guru.

Dari hasil wawancara dan pengamatan peneliti menemukan bahwa teknik yang digunakan dalam supervise sangat membantu guru dalam pelaksanaan kegiatan belajar mengajar yang 
dilakukan didalam kelas baik penyajian materi, metode yang digunakan dan memberi kesimpulan akhir sehingga tampak interaksi positif diantara guru dan siswa selama proses pembelajaran.

\section{Upayah atau tindak lanjut yang diakukan dalam meningkatkan profesionalisme guru}

Selaku kepala sekolah tindak lanjut yang dilakukan sekolah dalam upaya peningkatan profesionalisme guru adalah dengan cara mengirim guru-guru untuk melakukan pelatihan-pelatihanyang berkaitan dengan pembelajaran, mengadakan pelatihan tentang informasi dan teknologi bagi guru dan pegawai yang diadakan oleh pihak sekolah, sekolah juga melakukan musyawara guru mata pelajaran (MGMP) dalam rayon dan biasanya dilakukan persemester. Yang dibicarakan adalah tentang kendalah dalam proses pembelajaran, penggunaan alat peraga.

untuk memperkuat hasil wawancara diatas maka penelitipun mewawancarai beberapa orang guru. Hasil wawancara dengan guru mengatakan bahwa mereka pernah disupervisi oleh kepala sekolah dan yang disupervisi adalah menyangkut dengan administrasi dan perangkat pembelajaran. Supervise akademik yang dilakukan biasanya mellui perkunjungan kelas, observasi dan wawancara. Pada saat melakukan supervise biasanya tidak diberitahu terlebih dahulu. Setelah melakukan supervise guru biasanya dipanggil kedalam ruangan kepala sekolah untuk melakukan perbaikan-perbaikan atas kekurangan yang dialami oleh guru pada saat proses pembelajaran.

\section{Simpulan dan saran \\ Simpulan}

Berdasarkan hasil penelitian dapat disimpulkan bahwa supervise akademik yang dilakukan oleh kepala sekolah memiliki efek yang sangat baik dalam rangka meningkatkan profesionalisme guru pada umumnya dan sekolah SMP Negeri 1 Ndona khususnya. Dari data yang ada menunjukan bahwa peran kepala sekolah dalam meningkatkan profesionalisme guru sangat baik dengan dilakukan kegiatan-kegiatan penunjang dengan cara mengirim guru-guru untuk mengikuti berbagai pelatihanpelatihan serta mengadakan pelatihan informasi dan teknologi dan mengikutsertakan guru dalam kegiatan musyawara guru mata pelajaran.

Saran

Program supervise terus dilakukan dalam meningkatkan profesionalisme guru dan perbanyak mengikut sertakan guru-guru dalam berbagai macam kegiatan baik itu pelatihan maupun kegiatan lainya yang menunjang profesi guru itu sendiri.

\section{Daftar Pustaka}

Arikunto, 1990. Dasar-Dasar Evaluasi Pendidikan. Jakarta : Bumi. Aksara

Arikunto, (2004), dasar-dasar supervise, Jakarta; Rineka Cipta

Dadang.(2010). Supervisi Profesional (layanan dalam meningkatkan mutu pembelajaran di era otonomi daerah). Bandung; Alfabeta

Iman Sutadj. (1994). Petunjuk pelaksanaan supervise disekolah. Jakarta;departemen pendidikan dan kebudayaan direktorat pendidikan dasar dan menengah.

Koenjaraningrat.(2003). Metodologi penelitian. Jakarta; Gramedia

(Trianto, 2007 Model-model pembelajaran inovatif berorientasi konstruktivistik Jakarta. Prestasi Pustaka Publisher.

E. Mulyasa, 2003 Manajemen Berbasis Sekolah, Konsep Strategi dan Implementasi, Bandung:

Rosdakarya,

Mulyasa, 2004 Kurikulum Berbasis Kompetensi:

Konsep, Karakteristik Bandung: Rosdakarya,

John Dewei . 2001. Experience and Education. Bandung:Teraju (terjemahan). 